\title{
SARS-CoV-2 pandemic: potential relationship between psychiatric disorders and
}

\section{pulpits}

\author{
Pandemia de SARS-CoV-2: relação potencial entre transtornos psiquiátricos e pulpite \\ Pandemia SARS-CoV-2: relación potencial entre transtornos psiquiátricos y la pulpitis
}

Received: 09/08/2021 | Reviewed: 09/20/2021 | Accept: 10/04/2021| Published: 10/05/2021

\author{
Rodrigo Arruda-Vasconcelos \\ ORCID: https://orcid.org/0000-0002-0968-0212 \\ Universidade Estadual de Campinas, Brasil \\ E-mail: vasconcelosra@yahoo.com.br \\ Lidiane Mendes Louzada \\ ORCID: https://orcid.org/0000-0002-3480-8433 \\ Universidade Estadual de Campinas, Brasil \\ E-mail: lidiane.mlouzada@gmail.com \\ Esdras Gabriel Alves-Silva \\ ORCID: https://orcid.org/0000-0003-3223-8518 \\ Universidade Estadual de Campinas, Brasil \\ E-mail: esdras0702@yahoo.com.br \\ Rebecca Figueiredo de Almeida-Gomes \\ ORCID: https://orcid.org/0000-0002-8207-4163 \\ Centro Universitário Lusíada, Brasil \\ E-mail: rebeccaagomes@outlook.com \\ Henrico Badaoui Strazzi-Sahyon \\ ORCID: https://orcid.org/0000-0001-7014-0437 \\ Universidade Estadual Paulista Júlio de Mesquita Filho, Brasil \\ E-mail: ico_strazzi@hotmail.com \\ Paulo Henrique dos Santos \\ ORCID: https://orcid.org/0000-0002-4188-7766 \\ Universidade Estadual Paulista Júlio de Mesquita Filho, Brasil \\ E-mail: paulo.santos@unesp.br \\ Brenda Paula Figueiredo de Almeida Gomes \\ ORCID: https://orcid.org/0000-0002-8449-0646 \\ Universidade Estadual de Campinas, Brasil \\ E-mail: bpfagomes@fop.br
}

\begin{abstract}
The coronavirus outbreak is a global public health emergency with high transmission among the population. Over 18 million people were affected globally (06th August 2020). In most of the cases, patients present flu-like symptoms, such as fever, cough, headaches and myalgias are commonly reported. Lockdown measures have been implemented to control the spread of the virus. In contrast, these measures have been reported to increase the probability of psychological and physical disorders. As the pandemic intensifies, the number of patients seeking dental emergency services due to acute symptoms (i.e. pulpitis, acute apical abscesses) has increased. There is an increasing need to investigate the association between psychological disorders and dental emergencies. There is critical need for the development of public policies for mental and dental health worldwide, leading to the improvement in the quality of life of the population.
\end{abstract}

Keywords: COVID-19; Mental disorders; Pulpitis, SARS-CoV-2.

\section{Resumo}

O surto de coronavírus é uma emergência global de saúde pública com alta transmissão entre a população. Mais de 18 milhões de pessoas foram afetadas globalmente (06 de agosto de 2020). Na maioria dos casos, os pacientes apresentam sintomas semelhantes aos da gripe, como febre, tosse, dores de cabeça e mialgias. Medidas de bloqueio foram implementadas para controlar a propagação do vírus. Em contraste, relatou-se que essas medidas aumentam a probabilidade de distúrbios psicológicos e físicos. Conforme a pandemia se intensifica, o número de pacientes que procuram serviços de emergência odontológica devido a sintomas agudos (ou seja, pulpite, abscessos apicais agudos) aumentou. Há uma necessidade crescente de investigar a associação entre distúrbios psicológicos e emergências odontológicas. É crítica a necessidade de desenvolvimento de políticas públicas de saúde mental e bucal em todo o mundo, levando à melhoria da qualidade de vida da população.

Palavras-chave: COVID-19; Transtornos mentais; Pulpite, SARS-CoV-2. 


\begin{abstract}
Resumen
El brote de coronavirus es una emergencia de salud pública mundial con alta transmisión entre la población. Más de 18 millones de personas se vieron afectadas en todo el mundo (6 de agosto de 2020). En la mayoría de los casos, los pacientes con síntomas similares a los de la gripe, como fiebre, tos, dolores de cabeza y mialgia, son comúnmente reportados. Se han implementado medidas de bloqueo para controlar la propagación del virus. Por el contrario, se ha informado que estas medidas aumentan la probabilidad de trastornos psicológicos y físicos. A medida que la pandemia se intensifica, ha aumentado el número de pacientes que buscan servicios dentales de emergencia debido a síntomas agudos (es decir, pulpitis, abscesos apicales agudos). Existe una necesidad creciente de investigar la asociación entre los trastornos psicológicos y las emergencias dentales. Existe una necesidad crítica de desarrollar políticas públicas para la salud mental y dental en todo el mundo, que conduzcan a la mejora de la calidad de vida de la población.
\end{abstract}

Palabras clave: COVID-19; Trastornos mentales; Pulpitis, SARS-CoV-2.

\title{
1. Introduction
}

In December 2019, the coronavirus outbreak officially started in Wuhan, Hubei, China and characterised as a pandemic by the World Health Organization (WHO) on 11th March 2020 when 6,315 people were infected (World Health Organization). Undoubtedly, this outbreak represents a public health emergency on a global scale (The Lancet). On 23rd March 2021, the WHO confirmed 123,902,242 cases and 2,727,837 deaths (World Health Organization). Even after months into the pandemic, the world still faces ever increasing numbers of infections, with a recent record of 250,991 cases in a single day (World Health Organization).

Several symptoms have been associated with the coronavirus disease (COVID-19) including fever, dry cough, absence of nasal congestion, persistent headache, anorexia, dizziness, asthenia (lack of energy and strength), chills, myalgia, conjunctivitis, diarrhoea and nausea/vomiting in the early stages, and the more distinctive symptoms including anosmia (loss of smell), ageusia (loss of taste), dyspnoea, (shortness of breath), chest pain, haemoptysis and vascular lesions in the later stages (Carlos et al., 2019; Huang et al., 2020; Lee et al., 2020; Ren et al., 2020; Rothan et al., 2020; Wang et al., 2020; Gostin et al., 2020).

Lockdowns have been implemented as a measure to contain COVID-19 in several countries in order to minimise virus (SARS-CoV-2) transmission. As these measures were implemented, non-essential activities (i.e., pubs, restaurants, gyms, and stores) and those activities with the potential to cause agglomerations (i.e., schools and universities) were closed and travel restrictions were applied (Gostin et al., 2020).

As a consequence of all the restrictive measures, individuals are susceptible to deleterious effects on their mental and physical health (Hagger et al., 2020) and those presenting a history with symptoms of depression and anxiety may be more vulnerable. Previous studies have linked depression with inflammation, as detected by elevated levels of neutrophils, monocytes, CD4+ T cells, interleukin (IL)-6, C-reactive protein (CRP) and prostaglandin E2 (PGE2) (Zorrilla et al., 2001; Felger et al., 2020). Moreover, alterations in the tumour necrosis factor (TNF)- $\alpha$ system have also been reported to be associated with the development of psychiatric disorders and are related to changes in body weight, metabolism, and the endocrine system in psychiatric patients (Berthold-Losleben et al., 2008).

Symptomatic irreversible pulpitis refers to a severe degenerative process in the pulp tissue characterised by severe spontaneous pain or persistent pain after stimuli (Levin et al., 2009). The most common aetiologic factor related to inflammation of the pulp tissues is caries. After microbial invasion, different cells including neutrophils, monocytes and T cells are recruited into the site of injury (Rechenberg et al., 2016). Studies have reported increased levels of TNF- $\alpha$, IL-6 and CRP in teeth presenting irreversible pulpitis when compared to normal pulps (Proctor et al., 1991; Pezelj-Ribaric et al., 2002; Elsalhy et al., 2013). The levels of PGE2 in teeth with irreversible pulpitis have been associated with the degree of inflammation of the pulp tissue, higher in reversible pulpitis and lower in irreversible pulpitis, both conditions are characterised 
by exacerbated and prolonged pain (Petrini et al., 2012).

In an Endodontic perspective, PGE2 has been associated with several events including collagen degradation, vasodilatation and increasing vascular permeability (Martinho et al., 2011). IL-6 exhibits numerous biological effects and acts as a key mediator of the host response after tissue injury, infection, and inflammation (19). It also triggers the up regulation of adhesion molecules and stimulates angiogenesis leading to an increase in vascular permeability and oedema (Elsalhy et al., 2013). Additionally, IL-6 stimulates the production of CRP which is a member of the acute-phase reactants and belongs to a family of proteins involved in the innate immune response (Garrido et al., 2015). TNF- $\alpha$ is an important inflammatory mediator involved in the initial regulation of the host response, including the activation and expression of adhesion molecules, induction of the production of other cytokines and the proliferation of immune cells (Elsalhy et al., 2013).

Several studies have detected an increase in the percentage of patients undergoing dental treatment during isolation/quarantine due to acute symptoms (i.e., pulpitis). A study compared the dental procedure in an oral emergency service in China in 2019 (1,537 patients) and 2020 (1,422 patients) (Bai et al., 2020). Interestingly, the authors observed fewer total visits in 2020 when compared to 2019. On the other hand, a significant increase in the number of patients presenting acute symptoms including pulpitis was observed [2019: 278 cases (18.09\%); 2020: 348 cases (24.5\%)], acute apical periodontitis [2019: 143 cases (9.3\%); 2020: 158 cases (11.1\%)] and abscess [2019: 147 cases (9.56\%); 2020: 184 cases (12.9\%)]. A lower incidence in the need for procedures involving dental trauma, soft tissue injury and caries was observed (Bai et al., 2020).

Guo et al., 2020 when evaluating the impact of COVID-9 on the utilization of emergency dental services (China), observed a reduction in the number of patients (1,567 pre-COVID-19 and 970 during COVID-19). However, the authors detected an increase in dental and oral infections from 51\% (pre-COVID-19) to $71.9 \%$ (during COVID-19) and a reduction in dental trauma from $14.2 \%$ (pre-COVID-19) to $10.5 \%$ (during COVID-19).

Furthermore, another study conducted in China evaluated 96 patients seeking dental treatment and observed that most of them (56\%) were admitted due to irreversible pulpitis (Yu et al., 2020). Additionally, a study analysing over 1,500 patients over a five-week period during the pre-peak and peak period of COVID-19 in the U.K. identified pulpitis/periapical pathologies in 958 individuals (63.4\%) (Grossman et al., 2020).

Recently, a case-control study has associated periodontitis with increased risk of intensive care unit admission, mechanical ventilation, and death of COVID-19 (Marouf et al., 2021), emphasizing the correlation between dental and health problems.

The development of the disease is related to the number and virulence of the microorganisms, and host response (Hobson., 1965). The biofilm formed in dental caries can destroy the tooth's protective barriers (i.e., enamel and dentine) and move towards the dental pulp causing little or no apparent symptoms. However, the host response is also influenced by external factors such as the mental disorders (including anxiety and depression) triggered by the fear of SARS-CoV-2 and the restrictive/isolation measures imposed during the outbreak. The truth is that outbreaks of infectious diseases, such as the current Coronavirus, can change all the habits of individuals and bring fear, which will affect their mental health, directly affecting their physical condition. In addition, the need for isolation ends up amplifying the problem.

While it is particularly important to stay informed and follow the authorities' recommendations, it is necessary to maintain healthy habits and the balance of emotions during this outbreak. The need for healthcare policies to provide psychological support, by presential or remote consults, should be assessed by the authorities. It could decrease the number of consultations due to the dental problems.

\section{Conclusion}

In conclusion, the increase in the number of patients seeking endodontic treatment due to acute symptomatology 
during the SARS-CoV-2 outbreak could be related to the change of the individual's habits and to the psychiatric disorders.

\section{Acknowledgments}

The authors would like to thank David Henry Moon for English proofreading and technical support. Supported by the São Paulo Research Foundation (FAPESP - 2015/23479-5, 2017/25242-8, 2019/10755-5, 2019/19300-0, 2021/08372-0), National Scientific and Technological Development Council (CNPq - 308162/2014-5, 303852/2019-4), Coordination for Improvement of Higher Education Personnel (CAPES - Finance Code 001) and the Fund for the Support of Education, Research and Extension of the State University of Campinas (FAEPEX - 2036/17). The authors deny any conflicts of interest.

\section{References}

Bai, J., Xu, T., Ji, AP., Sun, W., \& Huang, M. W. (2020). Impact of COVID-19 on oral emergency services. Int Dent J. 71 (1):27-31.

Berthold-Losleben, M., \& Himmerich, H. (2008). The TNF-alpha system: Functional aspects in depression, narcolepsy and psychopharmacology. Curr Neuropharmacol. 6 (3):193-202.

Carlos, W. G., Dela Cruz, C. S., Cao, B., Pasnick, S., \& Jamil, S. (2020). Novel Wuhan (2019-nCoV) coronavirus. Am J Respir Crit Care Med. 201 (4):P7-P8

Elsalhy, M., Azizieh, F., \& Raghupathy, R. (2013). Cytokines as diagnostic markers of pulpal inflammation. Int Endod J. 46 (6):573-80.

Felger, J. C., \& Miller, A. H. (2020). Identifying immunophenotypes of inflammation in depression: Dismantling the monolith. Biol Psychiatry. 88 (2):136-8.

Garrido, M., Dezerega, A., Bordagaray, M. J., et al. (2015). C-reactive protein expression is up-regulated in apical lesions of endodontic origin in association with interleukin-6. J Endod. 41 (4):464-9.

Gostin, L. O., \& Wiley, L. F. (2020). Governmental public health powers during the COVID-19 pandemic: Stay-at-home orders, business closures, and travel restrictions. JAMA. $323(21): 2137-8$.

Grossman, S., Sandhu, P., Sproat, C., \& Patel, V. (2020). Provision of dental services at a single institution in the UK's epicentre during the COVID-19 pandemic. Br Dent J. 228 (12):964-70.

Guo, H., Zhou, Y., Liu, X., \& Tan, J. (2020). The impact of the COVID-19 epidemic on the utilization of emergency dental services. J Dent Sci. 15(4):564567

Hagger, M. S., Keech, J. J., \& Hamilton, K. (2020). Managing stress during the coronavirus disease 2019 pandemic and beyond: Reappraisal and mindset approaches. Stress Health. 36 (3):396-401.

Hobson, P. (1965). The bacteriological problems of root canals therapy. Dental Practitioner and Dental Records. 16 (2):43-7.

Huang, C., Wang, Y., Li, X., et al. (2020). Clinical features of patients infected with 2019 novel coronavirus in Wuhan, China. Lancet. 395 (10223):497-506.

Lee, Y., Min, P., Lee, S., \& Kim, S. W. (2020). Prevalence and duration of acute loss of smell or taste in COVID-19 Patients. J Korean Med Sci. 35 (18):174.

Levin, L. G., Law, A. S., Holland, G. R., Abbott, P. V., \& Roda, R. S. (2009). Identify and define all diagnostic terms for pulpal health and disease states. J Endod. 35 (12), 1645-57.

Marouf, N., Cai, W., Said, K. N., et al. (2021). Association between periodontitis and severity of COVID-19 infection: A case-control study. J Clin Periodontol. 48 (4):483-491

Martinho, F. C., Chiesa, W. M., Leite, F. R., Cirelli, J. A., \& Gomes, B. P. (2011). Antigenicity of primary endodontic infection against macrophages by the levels of PGE(2) production. J Endod. 37 (5):602-7.

Petrini, M., Ferrante, M., Ciavarelli, L., Brunetti, L., Vacca, M., \& Spoto, G. (2012). Prostaglandin E2 to diagnose between reversible and irreversible pulpitis. Int J Immunopathol Pharmacol. 25 (1):157-63.

Pezelj-Ribaric, S., Anic, I., Brekalo, I., Miletic, I., Hasan, M., \& Simunovic-Soskic, M. (2002) Detection of tumor necrosis factor alpha in normal and inflamed human dental pulps. Arch Med Res. 33 (5):482-4.

Proctor, M. E., Turner, D. W., Kaminski, E. J., Osetek, E. M., \& Heuer, M. A. (1991). Determination and relationship of C-reactive protein in human dental pulps and in serum. J Endod. 17 (6):265-70.

Rechenberg, D. K., Galicia, J. C., \& Peters, O. A. (2016). Biological markers for pulpal inflammation: A systematic review. PLoS One. 11 (11): 0167289.

Ren, L. L., Wang, Y. M., Wu, Z. Q., et al. (2020). Identification of a novel coronavirus causing severe pneumonia in human: a descriptive study. Chin Med J (Engl). 133 (9):1015-24.

Rothan, H. A., \& Byrareddy, S. N. (2020). The epidemiology and pathogenesis of Coronavirus Disease (COVID-19) outbreak. J Autoimmun. 109 (1):102433.

The Lancet. Emerging understandings of COVID-19. Lancet. (2020). 395 (10221):311. 
Research, Society and Development, v. 10, n. 13, e97101320372, 2021

(CC BY 4.0) | ISSN 2525-3409 | DOI: http://dx.doi.org/10.33448/rsd-v10i13.20372

Wang, W., Tang, J \& Wei, F. (2020). Updated understanding of the outbreak of 2019 novel coronavirus (2019-nCoV) in Wuhan, China. J Med Virol. 92 (4):441-7.

World Health Organization (WHO). https://covid19.who.int/

World Health Organization (WHO). https://www.who.int/emergencies/diseases/novel-coronavirus-2019/events-as-they-happen.

Yu, J., Zhang, T., Zhao, D., Haapasalo, M \& Shen Y. (2020). Characteristics of endodontic emergencies during coronavirus disease 2019 outbreak in Wuhan. J Endod. 46 (6):730-5.

Zorrilla, E. P., Luborsky, L., McKay, J. R., et al. (2001). The relationship of depression and stressors to immunological assays: a meta-analytic review. Brain Behav Immun. 15 (3):199-226. 